\title{
Use of Materials
}

\section{with Thermomechanical Shape Memory for Sollution of the Applied Problems in Construction Engineering Complex}

\author{
Vladimir E. Afanasyev*a, \\ Igor M. Kondrakov ${ }^{\mathrm{b}}$ and Viktor I. Zhadanov ${ }^{\mathrm{c}}$ \\ ${ }^{a}$ Siberian Federal University \\ 79 Svobodny, Krasnoyarsk, 660041, Russia \\ ${ }^{b}$ North-Caucasian Branch \\ of Belgorod State Technological University \\ 24 Railwaymen, Mineralnye Vody, 357202, Russia \\ ${ }^{c}$ Orenburg State University \\ 13 Pobedy, Orenburg, 460352, Russia
}

The article deals with the unique alloy on the basis of titanium nickelide with thermomechanical shape memory. It is spoken in detail about the alloy's memory effect phenomenology. The main reasons constraining the application of alloys with shape memory in the production technologies in different branches of technology, including constructing industry are reflected. The efficient area of possible application of that kind of alloys is shown. In this article is also proposed a method of calculation of power elements, executed from titanium nickelide alloy, and also the examples of alloy's application in practice. It is shown that the offered technique of a preliminary temperature cycling of power elements made of titanium nickelide allows to reach the maximum possible straining and power characteristics.

Keywords: alloys with shape memory, a martensite, a temperature cycling, titanium nickelide, range of application, a calculation method, power element, straining and power characteristics.

Citation: Afanasyev V.E., Kondrakov I.M., Zhadanov V.I. Use of materials with thermomechanical shape memory for sollution of the applied problems in construction engineering complex, J. Sib. Fed. Univ. Eng. technol., 2016, 9(4), 529-535. DOI: 10.17516/1999-494X-2016-9-4-529-535.

(c) Siberian Federal University. All rights reserved

* Corresponding author E-mail address: v_158@mail.ru 


\title{
Применение материалов
}

\section{с термомеханической памятью формы}

\section{для решения прикладных задач}

в строительном комплексе

\author{
В.Е. Афанасьев ${ }^{\text {a }}$, И.М. Кондаков ${ }^{\tilde{\sigma}}$, В.И. Жаданов ${ }^{\mathrm{B}}$ \\ ${ }^{a}$ Сибирский федеральный университет \\ Россия, 660041, Красноярск, пр. Свободный, 79 \\ ${ }^{6}$ Северо-Кавказский филиал \\ Белгородского государственного \\ технологического университета \\ Россия, 357202, Ставропольский край \\ Минеральные Воды, Железноводская, 24 \\ ${ }^{8}$ Оренбургский государственный университет \\ Россия, 460352, Оренбург, 13 лет Победь
}

Рассмотрен уникальный сплав на основе никелида титана, обладающий термомеханической памятью формы. Описана феноменология эффекта памяти сплава. Отражены основные причины, сдерживающие применение сплавов с памятью формы в промышленных технологиях в различных областях техники, в том числе в строительной индустрии. Показана эффективная область возможного применения рассматриваемых сплавов. Приведена методика расчета силовых элементов, выполненных из сплава на основе никелида титана, а также конкретные примеры применения рассматриваемого сплава в практике решения прикладных задач строительного комплекса. Показано, что предложенная методика предварительного термоциклирования силовых элементов из никелида титана позволяет получить максимально возможные их деформационно-силовые характеристики.

Ключевые слова: сплавы с памятью формы, мартенсит, термоциклирование, эквиатомный состав, никелид титана, область применения, методика расчета, силовой элемент, деформационно-силовые характеристики.

\section{Introduction}

In 1949 the Soviet scientists G. V. Kurdyumov and L.G. Handrods discovered the shape memory effect of some metal alloys, also called as, second sort phase transition, and in 1980 theywere given a diploma on opening for No. 239 of this effect was issued to them. In 90-ies in the USSR physics created more than 200 unique alloys which have the thermomechanical shape memory. One of the unique alloys possessing the similar shape memory is titanium nickelide alloy (TiNi). This alloy played the main role in emergence of the new direction of physics of a solid body.

The optimum combination of physical and mechanical characteristics allowed to use alloys with shape memory in many industries, in particular, in space technologies, the medical equipment, a mining industry, by production of temperature sensors and drives, and also in the robotized devices. Thus in the field of construction technologies application of alloys with shape memory very limited in Russia, and also abroad. First of it is connected all with specific features of the construction systems different from others with difficult stress - deformed condition, effect of sign-variable loadings, often 
due to difficult exploitation conditions at the same time at the essential range of temperature and moist oscillation.

Thus there is no doubt that expansion of scope of alloys with shape memory in sphere of construction technologies raises nowadays and opens a lot of opportunities to increase technical and economical efficiency of building constructions.

\section{Object of research}

Power element made of titanium nickelide with a diameter of $1,2 \mathrm{~mm}$ and $100 \mathrm{~mm}$ long with a temperature of the beginning of the inverse martensitic transition 120 degrees Celsius.

\section{Research purpose}

Experimental researches of preliminary thermocycling modes, allowing to raise deformation and power characteristics of power elements from shape memory alloys.

\section{Research technique}

Heating of a power element with variable loading with Joule heat by a transmission of electric current through it and natural cooling with axial deformation under the constant loading.

\section{Research results}

The phenomenology of a memory effect consists in the following. If we give any initial form for the alloy blank at the temperature of $T_{d}$, which is higher than temperature of direct martensitic transformation $M_{n}$, and then cool it up to the temperatures which provide the process of martensitic transformation (below $M_{k}$ ), and deform it so, that it will have a new form, that's when after heating it to the temperature, which is higher than in the end of the inverse martensitic transformation $A_{k}$, the alloy blank restores its initial form [1 - 4]. In the next thermocycle when the alloy blank achieve the temperature of the beginning of the inverse martensitic transformation $A_{n}$, it will start returning that form which was given to it when the temperature was higher than $A_{k}$.

In the course of initial form restoration in case when there are resistance forces $\left(P_{r}\right)$, in a sample is generated a reactive tension $\sigma_{r}$ which is equal [5]:

$$
\sigma_{r}=(1-\xi)\left(\sigma_{o}+\sigma_{m} \xi\right)
$$

$\sigma_{o}-$ the maximum value of reactive tension when the amount of returned deformations is $\varepsilon=\varepsilon_{s m}=\frac{\Delta L_{s m}}{\Delta L_{e}}=0$ during the loading rate and the value of returned deformations in the "idling" working stroke;

$\xi=\frac{\varepsilon}{\varepsilon_{o}}-$ coefficient of ratio of relative deformations, at the same time $\varepsilon_{o}-$ the maximum possible value of relative deformation of the working stroke in the absence of external loading; $\Delta L_{s m}$ - the value of the returned shape memory deformation during heating and in the presence of resistance forces $P_{r}$; 
$\Delta L_{e}$ - the value of the returned shape memory deformation during heating without resistance forces $P_{r}$, that is the value of the "idling" working stroke;

$\sigma_{m}-$ material fluidity limit, which equals to: $\sigma_{m} \approx \frac{\sigma_{o}}{2}$.

These material properties with shape memory are applied in various power devices in which the power elements are used as a working body and also which have the corresponding deformation power characteristics $\left(\sigma_{r}\right.$ и $\left.\Delta L_{s m}\right)$.

The researches of materials possessing shape memory showed that the most effective specific working capacity of power elements is in an interval $0,382<\xi \leq 0,618 \mathrm{~A}_{\max }$, having the highest specific working capacity $\mathrm{A}_{\mathrm{sp}}=\mathrm{A}_{\max }$, that is in the presence of "a golden proportion".

However, as a rule, in these devices is used one of deformation and power characteristics $\left(\sigma_{r}, A_{s p}\right.$, $\left.\Delta L_{s m}, \in\right)$ which in the set conditions can have the highest value. Besides, ignorance of some material properties features, inability to operate them during a working cycle leads to its misuse, which is shown in accumulation of irreversible plastic strain by material not only during the long loading, exceeding a fluidity limit but also at much smaller tension [5].

It is also known that it is necessary to use considerably the smaller efforts of stretching to the material subjected to numerous thermotraining $P_{p},<<P_{r}$, as the crystal lattice of material gets an ability to deform in a focused area in focused direction even in lack of loading $P_{p}$ in a martensitic phase (at a stage of its cooling). Thus material very badly exposes to mechanized conversion, especially lamellar power elements (cutting, drilling, etc.).

All these features of materials with shape memory lead to delay of their implementation in specific technical systems in various areas of technology, including construction engineering industry.

For elimination of these obstacles it is expedient to reach the following optimum combination of deformation and power characteristics of power elements: reactive tension $\sigma_{r} \rightarrow \max$; ; tension of power element deformation with length equal to $\mathrm{L}$ in a martensitic phase $\sigma_{p} \rightarrow \min ; \sigma_{m}-\sigma_{m} \rightarrow \max$; permanent plastic strain $\varepsilon_{p l} \rightarrow 0$; working stroke - the returned deformation $\Delta L_{s m} \rightarrow \max$ and possibility of material processing with usual means.

For the solution of the specified problems it was offered to adapt the material during all thermocycle of preliminary thermotraining for those conditions which provide manifestation of the most effective in these conditions deformation and power characteristics:

1. Loading of a power element in the range of heating from $A_{n}$ temperature up to the $>A_{k}$ temperature of direct martensitic transformation up to obtaining the maximum reactive tension $\sigma_{r} \rightarrow \max$.

2. Sudden removal of loading right after obtaining $\sigma_{r} \rightarrow \max$.

3. Cooling and platoon ("cold" deformation) of a power element for a new cycle.

Reset of loading according to the first scheme of loading in case when $T>A_{k}$ showed, that it creates special conditions in material for full run the martensitic transformations therefore the amount of a part of plastic deformation which turned in irreversible earlier, becomes reversible $\Delta L_{d}$.

The value of the full working stroke will be:

$$
\Delta L_{n r}^{\prime}=\Delta L_{r}+\Delta L_{d}^{\prime}
$$


$\Delta L_{r}$ - the value of power element working stroke or of the returned part of an absolute value of deformation $\varepsilon_{n \phi} \varepsilon_{\ddot{p}}$ at the martensitic transformations;

$\Delta L^{\prime}{ }_{d}$ - part of the plastic deformation returned by a power element after the reset of loading.

Thus the most optimum conditions, satisfying requirements of this problem, is the interval of values of relative deformation $\varepsilon$, which are in limits of "golden section", that is in case of obtaining the maximum specific working capacity $A_{s p}$ of a power element material (Fig. 1).

Specific working capacity $A_{s p}$ reflects ability of material to make the useful work per unit of volume of power element material [2]. Specific working capacity depends on $\varepsilon_{o}, \sigma_{o}, \sigma_{r} \leq \sigma_{m}$ and $\sigma_{m}$ [5], that is.:

$$
\begin{aligned}
& A_{s p}=4 \mathrm{~A}_{o} \frac{\sigma_{r}}{\sigma_{o}}\left(1-\frac{\sigma_{r}}{\sigma_{o}}\right)-\sigma_{r} \varepsilon ; \\
& \mathrm{A}_{o}=\sigma_{o} \varepsilon_{o}=\frac{\varepsilon_{o}}{2} \sigma_{o} .
\end{aligned}
$$

These dependences were used in a process of developing a number of devices, including the devices for needs of a construction engineering complex.

The most efficient sphere of application of alloys with shape memory in the field of construction engineering is the situation when it is necessary to do mechanical work in conditions of changing the outdoor temperature. It is because the alloy possessing shape memory carries out at once several functions. It at the same time it is a temperature sensor, the processor and the actuation mechanism. Thus, by the changing a ratio of a titanium and nickel in the process of melting, it is possible to set the operation temperature in its wide range beginning from the negative and up to the positive in advance.

So, for example, the power element of titanium nickelide alloy with an trip point of zero degrees Celsius can be applied in the device to prevent freezing of pipelines [6]. In this construction, it opens

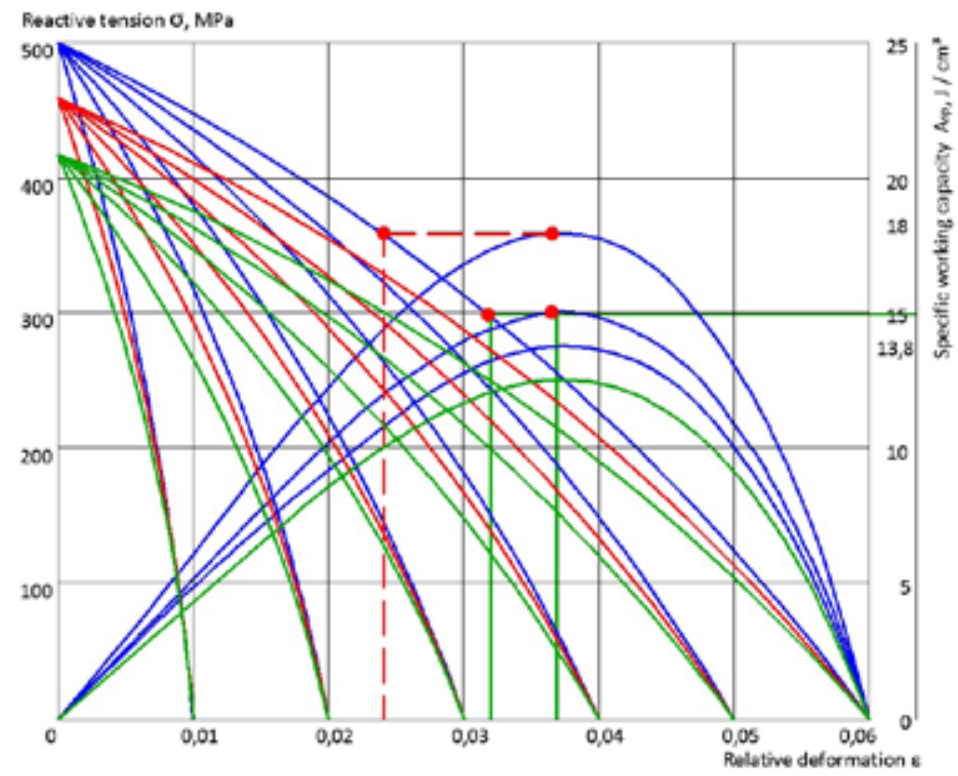

Fig. 1. Dependence of reactive tension from specific working capacity of material and relative deformation 
the valve of spout hole in the pipeline if temperature of the pumped-over liquid comes nearer to a point of phase transition to a solid body. In this case, it is a phase transition of the second sort of "martensiteaustenite" type prevents emergence of the usual.

In the conditions of the degrading permafrost, it is very important to know about the current value of thawing depth of a soil near the bases of buildings and constructions. It is caused by change of their bearing capacity. If in city conditions, it is possible quickly to control situation, than on constructions of big extent like power lines it is extremely difficult to receive such information. Now this function is carried out by team of the experts who are carrying out flights by helicopter with landing near each support of the high voltage line. The technology of determination of the frozen soil thawing depth consists of its intubation by metal probes.

Meanwhile, the power element from an alloy with shape memory programmed to do the mechanical work in time of obtaining the temperature of zero degrees Celsius could also assume the similar function. Such element can be previously buried on the critical thawing depth of permafrost soil on each support. After obtaining of this elevation number by the thermal front, it could give a unique signal, for example, turning on a disposable radio transmitter which signal is reflected in a supervisory console. In that case, it becomes clear, where exactly it is necessary to hold a complex of measures to prevent the threat of capsizing of a support of the high voltage line [7].

The highest working capacity of power elements material is obtained when $A s p=A_{o}$, that is $\sigma_{r}=\sigma_{m}$, when value of reactive tension is in the limits of "golden section".

Laboratory researches of power elements made of material with shape memory confirmed the theoretical calculations. Thus, the criterion allowing to receive an interval of values of deformation and power characteristics before experiment, lying within "golden section" is received (Fig. 2).

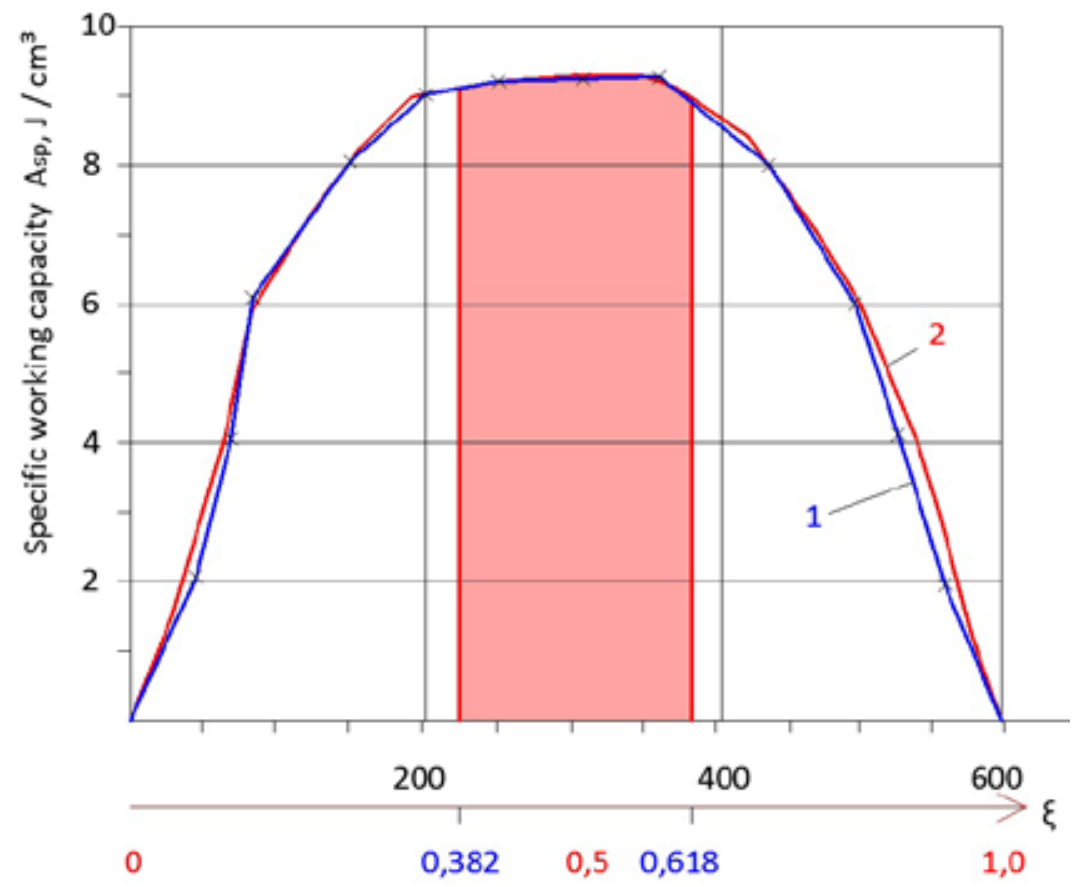

Fig. 2. Dependence of specific working capacity $A_{\mathrm{sp}}=\mathrm{f}(\varepsilon)$ when $\sigma_{r}=210 \mathrm{MPa}$ 


\section{Conclusions}

The offered technique of a preliminary temperature cycling of power elements made from titanium nickelide allows to receive their maximum possible deformation and power characteristics that allows to use successfully the similar alloys for the solution of the whole range of applied problems including the problems of construction engineering complex.

\section{References}

[1] Хачин В.Н. Память формыл. М.: Знание, 1984. 64 с. [Hachin V. N. Shape memory. Moscow, Znanie, 1984. 64 p. (in Russian)]

[2] Хачин В.Н. Мартенситная неупругость сплавов. Известия высших учебных заведений. T. ХХVII, раздел «Физика», 1985, № 5, 88-103. [Hachin V. N. Martensite unelasticity of alloys. Magazine of News of higher educational institutions. T. XXVII, section "Physics", № 5, 1985, 88-103 (in Russian)]

[3] Лихачев В.А., Кузьмин С.Л., Каменцева З.П. Эффект памяти формыл. Л.: Изд-во Ленингр. ун-та, 1987. 216 с. [Likhachev V.A., Kuzmin S. L., Kamentseva Z.P. Shape memory effect. Leningrad, Leningrad University, 1987. 216 p. (in Russian)]

[4] Фунакубо Х., Ооцука К., Симдзу К., Судзуки Ю. Сплавы с эффектом памяти формы. М.: Металлургия, 1990. 224 с. [Funakybo X., Ootsuka K., Simdzu K., Sudzuki Yu. Alloys with a shape memory effect. Moscow, Metallurgia, 1990. 224 p. (in Russian)]

[5] Кондраков И.М. Разработка и создание мартенситного привода машин для проходки скважин в массиве горных пород. Автореф. дис. ... канд. техн. наук. АН СССР СО ИГД. Новосибирск, 1988. 23 с. [Kondrakov I.M. Development and creation of the martensite car transmission for making wells in the rock's massifs. Novosibirsk, Academy of Sciences of the USSR of SO IGD, 1988. 23 p. (in Russian)]

[6] Тугужаков Д.Б., Афанасьев В.Е. Патент РФ на изобретение № 116599. Устройство для предотвращения замерзания трубопроводов. Опубл. 27.05.2012. Бюл. №15. 7 с. [Tuguzhakov D.B., Afanasyev V. E. Patent 116599. The device for prevention of pipelines freezing. Publ. 27.05.2012. Bul. № 15.7 p. (in Russian)]

[7] Саламатов Ю.П., Кондраков И.М., Афанасьев В.Е. А.с. 1339197. Сигнализатор критической глубины оттаивания мерзлого грунта. Опубл. 23.09.1987. Бюл. № 35. 6 c. [Salamatov Y.P., Kondrakov I.M., Afanasyev V. E. A.S. 1339197. Critical depth signaling device of frozen soil thawing. Publ. 23.09.1987. Bul. №35. 6 p. (in Russian)] 